\title{
The Effect of Compensation and Organizational Commitments to Turnover Intention with Work Satisfaction as Intervening Variables. Case Study at PT. BNI Life West Sumatra Region
}

\author{
Ulva Putra ${ }^{1}$, Erni Masdupi ${ }^{2}$ \\ 1Universitas Negeri Padang, Padang, Indonesia, $\bowtie$ ulvaputra094@gmail.com \\ 2Universitas Negeri Padang, Padang, Indonesia, $\bowtie$ emasdupi@yahoo.com \\ * Corresponding Author
}

\begin{abstract}
This study aims to determine the effect of compensation and organizational commitment on turnover intention with job satisfaction as an intervening variable. The object of this research is BNI Life employees in West Sumatra Region. The sampling technique used in this study was sample saturation with a total population of 97 respondents using Structural Equation Modeling (SEM) with the help of Partial Least Square (SmartPLS3) as data analysis. The results show that compensation has a negative effect on turnover intention, organizational commitment has a negative effect on turnover intention and job satisfaction has a negative effect on turnover intention, there is also a negative and indirect influence between organizational commitment to turnover intention and job satisfaction as an intervening variable and negative effects and indirectly between compensation for turnover intention and job satisfaction as an intervening variable
\end{abstract}

Keywords: compensation, organizational commitment, job satisfaction and turnover intention

\section{Introduction}

The company's performance can be damaged directly or indirectly by various employee behaviors. The employee's behavior is turnover intentions which can lead to the decision of the employee to leave his or her job, causing a negative impact on the organization, such as creating instability and uncertainty on labor conditions and increasing the cost of human resources in the form of training costs which has been invested in employees until the costs of recruitment and retraining.

Some of the turnover intention phenomena can be found in every company, including PT. BNI Life Insurance in West Sumatra. The following data shows employee turnover on PT. BNI Life Insurance in West Sumatra in 2014 to 2018 is shown in table 1

Table I Data Turnover Employees of PT. BNI Life Insurance in West Sumatra in 2014 - 2018

\begin{tabular}{ccccc} 
Year & $\begin{array}{c}\text { Number of } \\
\text { employees early } \\
\text { in the year }\end{array}$ & $\begin{array}{c}\text { Number of employees } \\
\text { coming out (\%) }\end{array}$ & $\begin{array}{c}\text { Number of } \\
\text { employees } \\
\text { entering }\end{array}$ & $\begin{array}{c}\text { Number of year- } \\
\text { end employees }\end{array}$ \\
\hline 2014 & 130 & $15(11,5 \%)$ & 7 & 122 \\
\hline 2015 & 122 & $13(10,6 \%)$ & 9 & 118 \\
\hline 2016 & 118 & $15(12,7 \%)$ & 8 & 111 \\
\hline 2017 & 111 & $16(14,4 \%)$ & 9 & 104 \\
\hline 2018 & 104 & $18(17,3 \%)$ & 11 & 97 \\
\hline
\end{tabular}

Source: PT. BNI Life Insurance (2018) 
Table 1 shows that the high turnover rate for BNI Life Insurance employees in West Sumatra starts from $10 \%$ to $17 \%$ while Simamora (1996) explains that the percentage rate or maximum turnover turnover rate is $2 \%$ because turnover must be balanced between additional employees and discharge. This shows that it is suspected that there are indications or factors that lead to a relatively high turnover intention

Wirawan [1] said that turnover is an employee quit from a company or organization and moves to another company for any reason. Turnover occurs because cognitive stages, which are thought to quit the job, intend to seek other employment alternatives, or intend to leave the job. This has a big impact on the company due to turnover on employees, so many researchers analyze the problem and obtain several factors that can be done to reduce the level of turnover intention in the company. Some of these factors are compensation, organizational commitment and job satisfaction

Compensation is one of the main requirements needed by an employee as a human being to make a living. Giving compensation must be fair and equitable in order to create a conducive and productive work environment for the company. Mathis \& Jackson (2012) states that compensation is an important factor that influences how and why people work in a company and not in other companies

Another factor that can trigger the formation of employee behavior to leave work (turnover intention) is organizational commitment. Wibowo (2016) says that organizational commitment is defined as the willingness of some workers to remain as members of the organization. Organizational commitment affects whether workers remain as members of the organization or leave the organization and look for new jobs.

This shows that organizational commitment will be established to increase engagement between individuals and organizations. employee commitment to the organization needs to be built in order to increase engagement between individuals and organizations. employee commitment to the organization will make employees loyal to the organization and work well for the benefit of the organization

The last factor that can trigger the formation of employee behavior to leave work (turnover intention) is job satisfaction. Mobley (1997) states that job dissatisfaction with employees can be expressed in various employee behaviors, for example in addition to leaving work, employees can complain, disobey and avoid some of their responsibilities therefore job satisfaction has a negative relationship with employee discharge (turnover intention).

On the basis of various problems and description phenomena above, the research is carried out with the title "The Effect of Compensation and Organizational Commitment to Turnover Intention with Job Satisfaction as an Intervening Variable (Case Study of PT. BNI Life Insurance in West Sumatra) with the aim of seeing the effect of compensation on turnover intention, organizational commitment to turnover intention, job satisfaction towards turnover intention and compensation for turnover intention with job satisfaction as a variable of mediation and organizational commitment to turnover intention with job satisfaction as a mediating variable.

\section{Compensation}

According to Hasibuan (2012) compensation is all income in the form of money, direct or indirect goods received by employees as compensation for services provided to the company. In general, according to Ulfatin, Nurul \& Teguh Triwiyanto [2] compensation is grouped into two dimensions: (1) Direct financial compensation: consists of payments obtained by someone in the form of salaries, wages and incentives. (2) Indirect Financial Compensation: is additional remuneration is given based on organizational policy for all employees in an effort to improve their welfare such as health benefits, vacations and retirement savings.

Organizational Commitment

Mathis \& Jackson [6] defines organizational commitment as the extent to which employees believe and accept organizational goals and will remain or not leave the organization. Dimensions Suparyadi [8] identified three model dimensions of organizational commitment, as follows: (1) Affective Commitment: The level of attachment of the organization based on how well the feeling towards the organization. this 
kind of commitment arises and is developed by encouragement of comfort, security, and other perceived benefits in an organization not obtained from other organizations. (2) Normative Commitments: Level of organizational attachment because of their moral obligation to maintain connections within the organization. In normative commitments, permanent members and contributing to the organization to fulfill their duties and responsibilities, and driven by moral obligations to fulfill psychological contracts, they have agreed with the organization. (3) Sustainable Commitments: Level of organizational attachment because of the costs they incur as a consequence if they quit the organization. In continuous commitment, members will calculate the ratio between the benefits they receive at the expense of their involvement in the organization

\section{Job Satisfaction}

According to Handoko (2010) job satisfaction (job satisfaction) as a pleasant or unpleasant emotional state and how employees perceive their work. Dimensions According to Anthony J, Celluci and David L (1978) there are four dimensions in job satisfaction as follows: (1) Satisfaction with promotional promotions: The opportunity for someone to reach or be promoted to a higher level in an organization. (2) Satisfaction with co-workers: The extent to which coworkers are technically clever and socially support the work of other colleagues. (3) Satisfaction with supervisor That is the ability of superiors to provide technical assistance in support of work that is the responsibility of their employees. (4) Satisfaction work itself: The extent to which work provides a person's opportunity to obtain responsibility in a particular task and challenge for interesting work

\section{Turnover Intention}

According to (Mahdi et al., 2012) turnover intention is the tendency of the employee's intention to go home, the organizational of the intention is submitted by the employee's decision or employee's intention is an important research that must be known by the organization or company. Dimensions Mobley \& Hollingsworth [3] there are three dimension of turnover intention such as: (1) Thinking of Quitting: Reflect individuals to think out of work or remain in the work environment. Beginning with job dissatisfaction felt by employees, then employees begin to think of leaving their current work place. (2) Intention to search alternatives: Reflects individuals wishing to find work in other organizations. If the employee has started to think often of leaving his job, the employee tries to find another job in the company that feels better. (3) Intention to Quit: Reflects individuals who intend to leave. Employees intend to leave if they have got a better job and later end with the employee's decision to stay or leave his job

\section{Framework and Hypothesis}

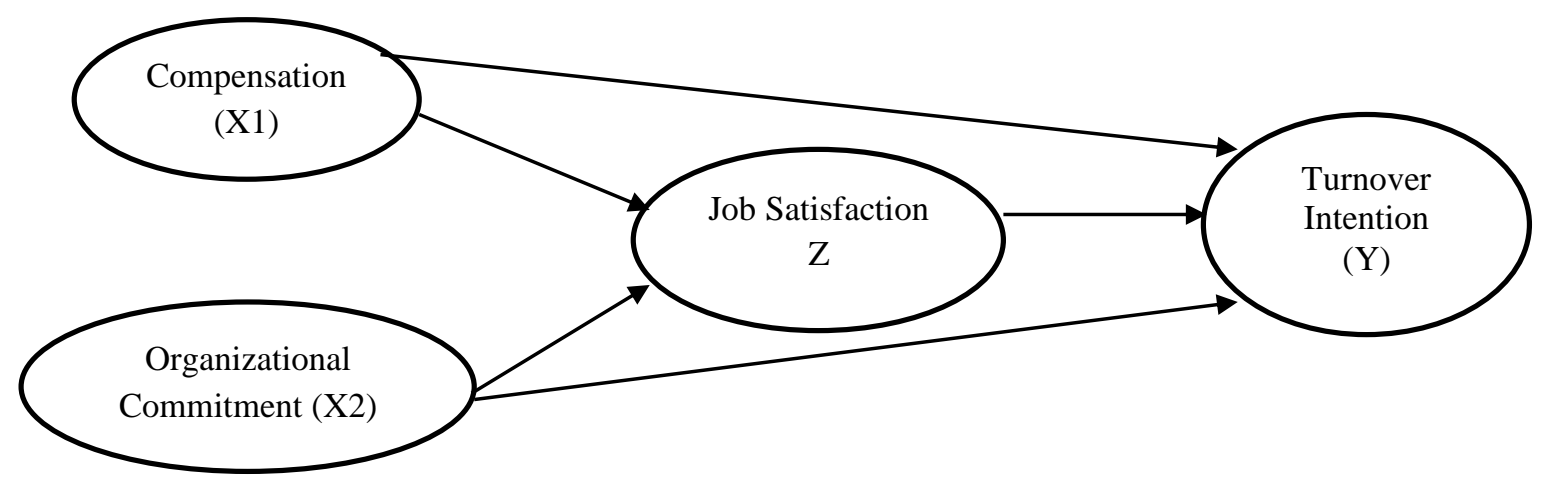

Figure 1 Conceptual framework

Based on the formulation of the problem and the basic theory described earlier, the hypothesis in this study are

$\mathrm{H} 1$ : Compensation affects turnover intention

$\mathrm{H} 2$ : Organizational commitment affects turnover intention 
H3 : Job satisfaction affects turnover intention

$\mathrm{H} 4$ : Compensation affects turnover intention through job satisfaction as an intervening variable

H5 : Organizational commitment affects turnover intention through job satisfaction as an intervening variable

\section{Methods}

This research began in March 2019 until May 2019, which was held at PT. BNI Life Insurance in West Sumatra Barat. The population studied was BNI Life employees throughout the Sumetera Barat branch with a total of 97 respondents. The sampling method used is the method of saturation sampling (census). Definition of saturation sampling (census) is a sampling technique if all members of the population are used as samples. This is often done when a relatively small number of populations are used, or research to make generalizations with very small errors sugiyono [9].

\section{Research Instruments}

The measurement method used in this study is a Likert scale. According to Sugiyono, the Likert Scale is used to measure attitudes, opinions, and someone or a group of perceptions about social phenomena. The answers to each instrument item using the Likert scale have a level of very positive to very negative. Data Analysis TechniquesData analysis was performed using SEM (Structural Equation Modeling) using Partial Least Square (PLS) analysis tools. Using Outer Model to measure the validity and reliability in this study the analytical technique used is the measurement model, and Inner Model Whereas for the measurement of significance between inter-variable constructs used the structural model analysis

\section{Results and Discussion}

\section{Descriptive Analysis}

Characteristics of Respondents

Respondent characteristics needed in this study such as, based on gender, age, position, monthly income of respondents

Based on Gender

Table 2 The proportion of respondents by sex

\begin{tabular}{llll}
\hline Number & \multicolumn{1}{c}{ Gender } & Number of people & Persentase \% \\
\hline 1 & Man & 18 & $18,6 \%$ \\
\hline 2 & Women & 79 & $81,4 \%$ \\
\hline & Total & 97 & $100 \%$ \\
\hline
\end{tabular}

Source: Primary data processed with SPSS

Based on Table 2, it can be concluded that the majority of the study respondents were female, as many as 79 people, or around $81.4 \%$, this was because the number of employees in BNI Life was also dominated by women

Based on age

Table 3 The proportion of respondents based on age

\begin{tabular}{rlcc}
\hline Number & Age & Number of people & Persentase $\%$ \\
\hline 1 & $20-30$ year & 80 & $82,5 \%$ \\
\hline 2 & 31-40 year & 15 & $15,5 \%$ \\
\hline 3 & 41-50 year & 2 & $2 \%$ \\
\hline & Total & 97 & $100 \%$ \\
\hline
\end{tabular}

Source: Primary data processed with SPSS 
Based on Table 3, it can be seen that the majority of respondents in this study were employees aged 20-30 years with a total of 80 people or $82.5 \%$. This is because more young people are needed to work in BNI Life.

Based on education

Table 4 The proportion of respondents based on education

\begin{tabular}{llll}
\hline Number & Education & Number of people & Persentase $\%$ \\
\hline 1 & SMA/SMK & 0 & $0 \%$ \\
\hline 2 & D1 & 0 & $0 \%$ \\
\hline 3 & D3 & 21 & $21,65 \%$ \\
\hline 5 & S1 & 76 & $78,35 \%$ \\
\hline & S2 & 0 & $0 \%$ \\
\hline
\end{tabular}

Source: Primary data processed with SPSS

Based on Position

Table 5 The proportion of respondents based on position

\begin{tabular}{rlcc}
\hline Number & Position & Number of people & Persentase $\%$ \\
\hline 1 & Inbranch & 72 & $74,2 \%$ \\
\hline 2 & Worksite & 10 & $10,3 \%$ \\
\hline 3 & ASM & 15 & $15,5 \%$ \\
\hline & Total & 97 & $100 \%$ \\
\hline
\end{tabular}

Source: Primary data processed with SPSS

Based on Table 5 it can be seen that the majority of BNI Life employees who were research respondents served as In branch as many as 72 people or $74.2 \%$. This is because employees who work at BNI Life are on average Fresh Graduate or new graduates who have just entered the workforce.

Based on Monthly Revenue

Table 6 The proportion of respondents based on Monthly

\begin{tabular}{clcc}
\hline Number & \multicolumn{1}{c}{ Monthly Revenue } & $\begin{array}{c}\text { Number of } \\
\text { people }\end{array}$ & Persentase \% \\
\hline 1 & $\operatorname{Rp~} 1.500 .000-\operatorname{Rp} 2.500 .000$ & 72 & $74,2 \%$ \\
\hline 2 & $\operatorname{Rp} 2.500 .000-\operatorname{Rp} 3.500 .000$ & 10 & $10,3 \%$ \\
\hline 3 & $\operatorname{Rp} 3.500 .000-\operatorname{Rp} 6.500 .000$ & 15 & $15,5 \%$ \\
\hline & Total & 97 & $100 \%$ \\
\hline
\end{tabular}

Source: Primary data processed with SPSS

Based on Table 6, it can be concluded that the majority of employees at BNI Life who are research respondents have monthly income of 1.5 million to 2.5 , which is 72 people or $74.2 \%$. This is because the income of employees who get in accordance with the position held by the majority of the positions of employees is as Inbranch in BNI Life 


\section{Descriptive Turnover Intention $(Y)$ variable frequency}

Table 7 Descriptive Respondents' Answers to Turnover Intention Variables

\begin{tabular}{|c|c|c|c|c|c|c|c|c|}
\hline \multirow[t]{2}{*}{ Item } & \multirow[t]{2}{*}{ Question } & \multicolumn{5}{|c|}{ Frequency of Answers } & \multirow[t]{2}{*}{ Mean } & \multirow[t]{2}{*}{ Category } \\
\hline & & 1 & 2 & 3 & 4 & 5 & & \\
\hline Y1 & I have the opportunity to leave the company & 0 & 19 & 0 & 59 & 19 & 3,80 & High \\
\hline Y2 & I want to leave my current job & 18 & 1 & 0 & 61 & 17 & 3,60 & High \\
\hline Y3 & I plan to find a new job in the near future & 0 & 19 & 0 & 56 & 22 & 3,84 & High \\
\hline & Turnover Intention $(\mathrm{Y})$ & & & & & & 3,7 & High \\
\hline
\end{tabular}

Source: Primary data processed with SPSS

Based on Table 7 it is known that the average value of respondents' answers to the turnover intention variable is 3.7 with a high category. This means that employees have the desire to leave the company. The highest turnover intention statement is the employee's plan to find a new job in the near future with a mean of 3.84 and the lowest turnover intention statement related to having the opportunity to leave the company table with a mean value of 3.60

\section{Descriptive Variable Frequency Compensation (X1)}

Table 8 Descriptive Respondents' Answers to Compensation Variables

\begin{tabular}{|c|c|c|c|c|c|c|c|c|}
\hline \multirow{2}{*}{ Item } & \multirow{2}{*}{ Question } & \multicolumn{5}{|c|}{ Frequency of Answers } & \multirow{2}{*}{ Mean } & \multirow{2}{*}{ Category } \\
\hline & & 1 & 2 & 3 & 4 & 5 & & \\
\hline $\mathrm{X} 1$ & Salary received as expected & 0 & 18 & 62 & 5 & 12 & 3,11 & High \\
\hline $\mathrm{X} 2$ & $\begin{array}{l}\text { The incentives provided are in accordance with } \\
\text { what you get }\end{array}$ & 2 & 69 & 8 & 18 & 0 & 2,43 & Low \\
\hline $\mathrm{X} 3$ & Allowances received are in line with expectations & 0 & 63 & 17 & 17 & 0 & 2,53 & Low \\
\hline $\mathrm{X} 4$ & $\begin{array}{l}\text { Satisfied with social security employment } \\
\text { provided by the company }\end{array}$ & 46 & 33 & 0 & 18 & 0 & 1,92 & Low \\
\hline $\mathrm{X} 5$ & $\begin{array}{l}\text { Satisfied with health insurance provided by the } \\
\text { company }\end{array}$ & 51 & 27 & 1 & 18 & 0 & 1,86 & Low \\
\hline $\mathrm{X} 6$ & $\begin{array}{l}\text { The company pays attention to meeting employee } \\
\text { needs and facilities }\end{array}$ & 49 & 30 & & 18 & 0 & 1,87 & Low \\
\hline & Kompensasi (X1) & & & & & & 1,86 & Low \\
\hline
\end{tabular}

Source: Primary data processed with SPSS

Based on Table 8 it is known that the average value of respondents' answers to the compensation variable is 1.86 with a low category. This means that employees receive low compensation. The lowest statement of compensation is the plan of health insurance provided by the company with a mean value of 1.86 and the highest statement of compensation related to the expected salary in the range with a mean of 3.11 . 
Descriptive Variable Frequency of Organizational Commitment (X2)

Table 9 Descriptive Respondents' Answers to Organizational Commitment Variables

\begin{tabular}{|c|c|c|c|c|c|c|c|c|}
\hline \multirow[t]{2}{*}{ Item } & \multirow[t]{2}{*}{ Question } & \multicolumn{5}{|c|}{$\begin{array}{l}\text { Frequency of } \\
\text { Answers }\end{array}$} & \multirow[t]{2}{*}{ Mean } & \multirow[t]{2}{*}{ Category } \\
\hline & & 1 & 2 & 3 & 4 & 5 & & \\
\hline $\mathrm{X} 2.1$ & $\begin{array}{l}\text { I will feel very happy to spend the rest of my } \\
\text { career at this company }\end{array}$ & 46 & 34 & 2 & 15 & 0 & 1,89 & Low \\
\hline$X 2.2$ & $\begin{array}{l}\text { I feel that the problem that happened at the } \\
\text { company was my problem too }\end{array}$ & 52 & 28 & 16 & 1 & 0 & 1,65 & Low \\
\hline $\mathrm{X} 2.3$ & $\begin{array}{l}\text { I feel that the problem that happened at the } \\
\text { company was my problem too }\end{array}$ & 13 & 63 & 4 & 17 & 0 & 2,26 & Low \\
\hline $\mathrm{X} 2.4$ & $\begin{array}{l}\text { I have difficulty leaving this company for fear of } \\
\text { not getting work opportunities elsewhere }\end{array}$ & 59 & 21 & 0 & 17 & 0 & 1,74 & Low \\
\hline $\mathrm{X} 2.5$ & $\begin{array}{l}\text { It would be too detrimental for me to leave this } \\
\text { company }\end{array}$ & 53 & 27 & 0 & 17 & 0 & 1,80 & Low \\
\hline $\mathrm{X} 2.6$ & It's hard to get a good income job like mine now & 56 & 24 & 0 & 16 & 1 & 1,78 & Low \\
\hline $\mathrm{X} 2.7$ & I feel this company has contributed a lot to my life & 17 & 65 & 0 & 0 & 15 & 2,32 & Low \\
\hline $\mathrm{X} 2.8$ & This company deserves loyalty from me & 38 & 42 & 0 & 1 & 16 & 2,12 & Low \\
\hline \multicolumn{2}{|c|}{ Organizational Commitment (X2) } & & & & & & 1,94 & Low \\
\hline
\end{tabular}

Source: Primary data processed with SPSS

Based on Table 9 it is known that the average value of the respondent's answer to the compensation variable is 1.94 with a low category. This means that the level of commitment felt by employees is low. The lowest statement of organizational commitment is the problem that occurs in the company becomes my problem as well with a mean value of 1.65 and the highest statement of organizational commitment that is related to me.

Descriptive Variable Frequency of Job Satisfaction $(Z)$

Table 10 Descriptive Respondents' Answers to Job Satisfaction Variables

\begin{tabular}{|c|c|c|c|c|c|c|c|c|}
\hline \multirow{2}{*}{ Item } & \multirow{2}{*}{ Question } & \multicolumn{5}{|c|}{ Frequency of Answers } & \multirow{2}{*}{ Mean } & \multirow{2}{*}{ Category } \\
\hline & & 1 & 2 & 3 & 4 & 5 & & \\
\hline $\mathrm{Z1}$ & $\begin{array}{l}\text { I feel satisfied with this job } \\
\text { because it is in accordance } \\
\text { with the abilities that I have }\end{array}$ & 3 & 65 & 13 & 16 & 0 & 2,45 & Low \\
\hline $\mathrm{Z} 2$ & $\begin{array}{l}\text { I feel satisfied with the } \\
\text { opportunity of self- } \\
\text { development given by the } \\
\text { company }\end{array}$ & 3 & 67 & 9 & 16 & 2 & 2,45 & Low \\
\hline
\end{tabular}


Table Cont...

\begin{tabular}{lllllllll}
\hline Z3 3 & $\begin{array}{l}\text { I feel satisfied with the } \\
\text { guidance given by superiors } \\
\text { in helping carry out the } \\
\text { work }\end{array}$ & 43 & 37 & 2 & 15 & 0 & 1,89 & Low \\
\hline Z4 $\begin{array}{l}\text { I feel satisfied with all my } \\
\text { colleagues in terms of } \\
\text { working together to } \\
\text { accomplish work }\end{array}$ & 39 & 16 & 0 & 0 & 1,66 & Low \\
\hline Job satisfaction $(\mathrm{Z})$ & & & & & & & & \\
\hline
\end{tabular}

Source: Primary data processed with SPSS

Based on Table 10 it is known that the average value of respondents' answers to the variable job satisfaction is 2.11 with a low category. This means that employees feel dissatisfied with work. The lowest satisfaction felt by employees is satisfaction with all colleagues in terms of cooperation in completing tasks with a mean value of 1.66 and the biggest statement of satisfaction felt by employees is satisfaction with this job because it is in accordance with the abilities that I have and satisfaction with selfdevelopment given company with a mean value of 2.45 .

\section{PLS Data Analysis}

Measurement Model (Outer Model / Measurement Model

Validity tes

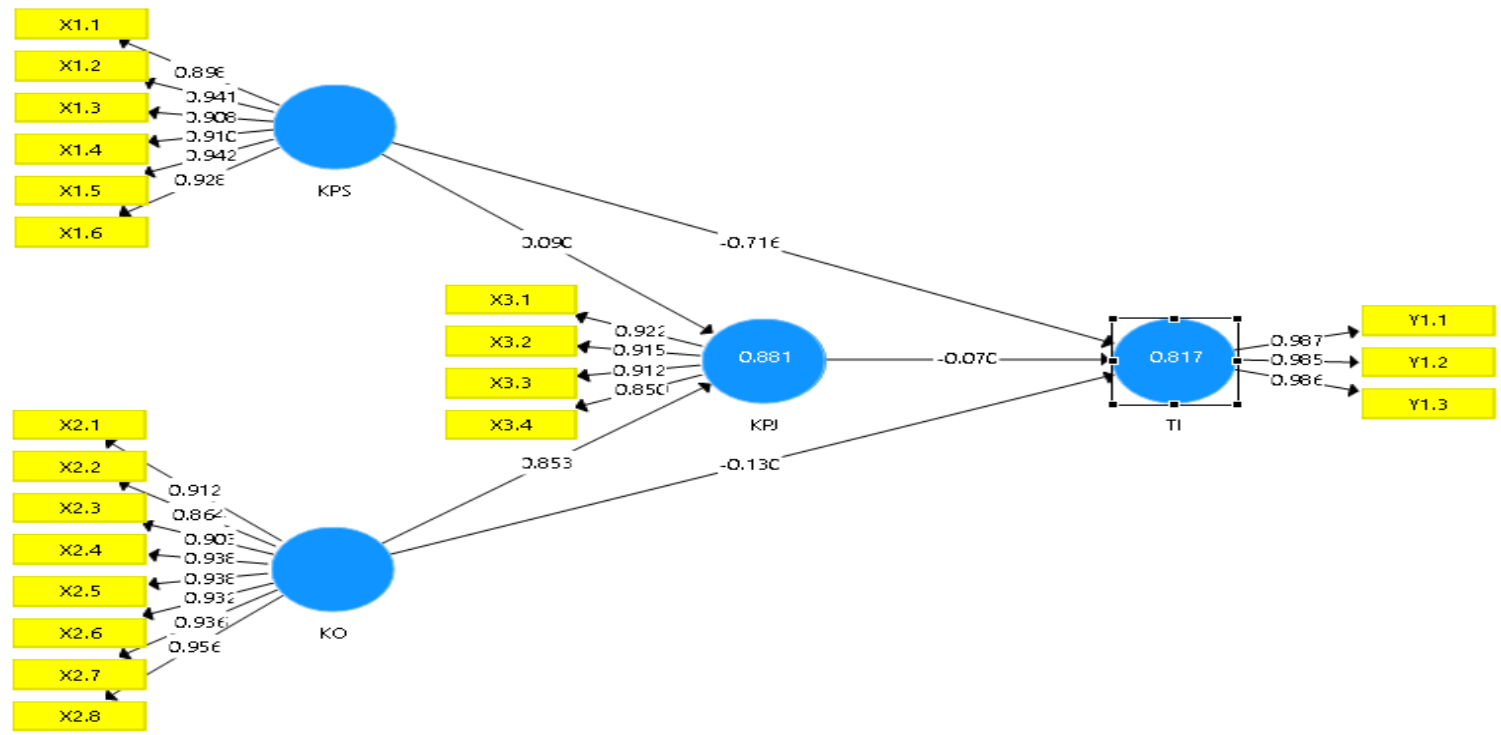

Figure 2 PLS Measurement Model (Re-Estimate)

Source: Results of processing with SmartPLS

After re-estimate by removing the variable indicator which is considered to have a loading factor of less than 0.5 , all the indicators of the variable are obtained that meet converging validity. The value of convergent validity is indicated by the final outer loading table: 
Table 11 Outer Loading (Re-Estimate)

\begin{tabular}{|c|c|c|}
\hline Variable & Indicator & Outer Loading \\
\hline & KPS01 & 0,898 \\
\hline & KPS02 & 0,941 \\
\hline \multirow[t]{6}{*}{ Compensation (X1) } & KPS03 & 0,908 \\
\hline & KPS04 & 0,910 \\
\hline & KPS05 & 0,942 \\
\hline & KPS06 & 0,928 \\
\hline & KO01 & 0,912 \\
\hline & $\mathrm{KO} 02$ & 0,864 \\
\hline \multicolumn{3}{|l|}{ Cont's Table } \\
\hline & $\mathrm{KO} 03$ & 0,903 \\
\hline \multirow[t]{6}{*}{ Organizational Commitment (X2) } & KO04 & 0,938 \\
\hline & $\mathrm{KO} 05$ & 0,938 \\
\hline & KO06 & 0,932 \\
\hline & $\mathrm{KO} 07$ & 0,936 \\
\hline & $\mathrm{KO} 08$ & 0,956 \\
\hline & KKJ01 & 0,922 \\
\hline \multirow[t]{4}{*}{ Job Satisfaction $(\mathrm{Z})$} & KKJ02 & 0,915 \\
\hline & KKJ03 & 0,912 \\
\hline & KKJ04 & 0,850 \\
\hline & TI01 & 0,987 \\
\hline \multirow[t]{2}{*}{ Turnover Intention $(\mathrm{Y})$} & TI02 & 0,985 \\
\hline & TI03 & 0,986 \\
\hline
\end{tabular}

Source: Results of processing with SmartPLS

Based on Table 11, it is known that the value of outer loading of each indicator in the variable compensation, organizational commitment, job satisfaction and turnover intention are all> 0.5. This means that the indicators used in this study have fulfilled convergent (valid) validity, so that all indicators can be used for further analysis.

Table 12 Outer Loading (Re-Estimate)

\begin{tabular}{lllll}
\hline Indicator & $\begin{array}{c}\text { Compensation } \\
(\mathbf{X 1})\end{array}$ & $\begin{array}{c}\text { Organizational } \\
\text { Commitment } \\
(\mathbf{X})\end{array}$ & $\begin{array}{c}\text { Job Satisfaction } \\
\mathbf{( Z )}\end{array}$ & $\begin{array}{c}\text { Turnover } \\
\text { Intention } \\
(\mathbf{Y})\end{array}$ \\
\hline KPS01 & 0,899 & 0,867 & 0,800 & $-0,756$ \\
\hline KPS02 & 0,941 & 0,874 & 0,833 & $-0,860$ \\
\hline KPS03 & 0,908 & 0,852 & 0,845 & $-0,820$ \\
\hline KPS04 & 0,910 & 0,889 & 0,806 & $-0,854$ \\
\hline KPS05 & 0,942 & 0,878 & 0,828 & $-0,839$ \\
\hline KPS06 & 0,928 & 0,874 & 0,848 & $-0,850$ \\
\hline KO01 & 0,894 & 0,912 & 0,848 & $-0,837$ \\
\hline
\end{tabular}


Table Cont...

\begin{tabular}{lllll}
\hline KO02 & 0,829 & 0,864 & 0,761 & $-0,785$ \\
\hline KO03 & 0,830 & 0,903 & 0,903 & $-0,783$ \\
\hline KO04 & 0,888 & 0,938 & 0,865 & $-0,811$ \\
\hline KO05 & 0,906 & 0,938 & 0,906 & $-0,800$ \\
\hline KO06 & 0,868 & 0,932 & 0,868 & $-0,810$ \\
\hline KO07 & 0,864 & 0,936 & 0,864 & $-0,819$ \\
\hline KO08 & 0,907 & 0,959 & 0,907 & $-0,801$ \\
\hline KKJ01 & 0,781 & 0,843 & 0,922 & $-0,716$ \\
\hline KKJ02 & 0,801 & 0,843 & 0,915 & $-0,720$ \\
\hline KKJ03 & 0,884 & 0,875 & 0,912 & $-0,825$ \\
\hline KKJ04 & 0,759 & 0,815 & 0,850 & $-0,738$ \\
\hline TI01 & $-0,876$ & $-0,850$ & $-0,822$ & 0,987 \\
\hline TI02 & $-0,914$ & $-0,885$ & $-0,835$ & 0,985 \\
\hline TI03 & $-0,875$ & $-0,851$ & $-0,810$ & 0,986
\end{tabular}

Source: Results of processing with SmartPLS

Another method for assessing discriminant validity is to look at average variance extracted (AVE) for each variable. Indicators of endogenous variables and exogenous variables are said to be valid if they have a value of AVE $>0.5$. Table 13 Analysis Results of Average Variance Extracted (AVE)

Table 13 Analysis Results of Average Variance Extracted (AVE)

\begin{tabular}{ll}
\hline \multicolumn{1}{c}{ Variable } & AVE \\
\hline Compensation & 0,849 \\
\hline Organizational Commitment & 0,851 \\
\hline Job Satisfaction & 0,811 \\
\hline Turnover Intention & 0,972
\end{tabular}

Source: Results of processing with SmartPLS

Based on Table 13above it can be concluded that each construct has a validity above 0.5 . It can be concluded that the indicators of latent variables have a good level of validity.

Reliability Test

Table 14 Data Reliability Analysis Results

\begin{tabular}{lcc}
\hline \multicolumn{1}{c}{ Variable } & Composite Reliability & Cronbachs Alpha \\
\hline Compensation & 0,971 & 0,964 \\
\hline Organizational Commitment & 0,979 & 0,975 \\
\hline Job Satisfaction & 0,945 & 0,922 \\
\hline Turnover Intention & 0,991 & 0,986 \\
\hline
\end{tabular}

Source: Results of processing with SmartPLS

Table 14 shows that the composite reliability value for all constructs is above 0.7 which indicates that all indicators of the estimated variables meet reliable criteria. 
Measurement Model (Inner Model / Structural Model)

R-Square Analysis

Table 15 Results of R-Square Analysis

\begin{tabular}{ll}
\hline \multicolumn{1}{c}{ Variable } & R-Square \\
\hline Compensation & \\
\hline Organizational Commitment & \\
\hline Job Satisfaction & 0,881 \\
\hline Turnover Intention & 0.817 \\
\hline
\end{tabular}

Source: Results of processing with SmartPLS

Table 15 shows that the R-square value of job satisfaction variables is 0.817 , which means $82 \%$ of turnover intention variables can be influenced by compensation variables, organizational commitment and job satisfaction. for the job satisfaction variable obtained at 0.881 , this result shows $89 \%$ of the variable job satisfaction can be influenced by variable compensation and organizational commitment. While for the compensation variable and organizational commitment does not have an R-square value because the two variables are not influenced by other variables in this study.

Goodness of Fit criteria

$$
\begin{aligned}
& =\frac{\mathrm{GOF}=\sqrt{\mathrm{AVE}} \times \overline{\mathrm{R}_{2}}}{4} \times \frac{0,881+0,817}{2} \\
& =0,933 \times 0,849 \\
& =0,79
\end{aligned}
$$

Based on the results above, it can be seen that the value of goodness of fit has a value of 0.84 which means that this criterion in the category of high / high is above $>0.38$ criteria of GOF Tanenhaus. big / high and good for causal relationships of variables in this study.

\section{Path Coefficients}

Table 16 Results of Path Coefficients

\begin{tabular}{lccccc}
\hline \multicolumn{1}{c}{ Variable } & $\begin{array}{c}\text { Original } \\
\text { Sample } \\
(\mathbf{O})\end{array}$ & $\begin{array}{c}\text { Sampel } \\
\text { Mean } \\
\mathbf{( M )}\end{array}$ & $\begin{array}{c}\text { Standard } \\
\text { Deviation } \\
\text { (STDEV) }\end{array}$ & $\begin{array}{c}\text { T.Statistic } \\
\text { (O/STERR) }\end{array}$ & $\begin{array}{c}\mathbf{P} \\
\text { Values }\end{array}$ \\
\hline Job Satisfaction- > Turnover Intention & -0.07 & $-0,107$ & 0.17 & 0,410 & 0,682 \\
\hline Organizational Commitment - > Job Satisfaction & 0,853 & 0,816 & 0,142 & 6,026 & 0,000 \\
\hline Organizational Commitment ->Turnover Intention & $-0,1430$ & $-0,201$ & 0,286 & 0,445 & 0,650 \\
\hline Compensation -> Job Satisfaction & 0,090 & 0,127 & 0,145 & 0,616 & 0,538 \\
\hline Compensation -> Turnover Intention & $-0,716$ & $-0,609$ & 0.329 & 2,174 & 0,030 \\
\hline
\end{tabular}

Source: Results of processing with SmartPLS

\section{Results}

\section{Effect of Compensation on Turnover Intention}

Based on the results of testing the research hypotheses using the SmartPLS 3 program it is known that the effect of compensation on turnover intention results in a path coefficient of -0.716 and t-count of 2.147. It can be concluded that compensation has a negative and significant effect on turnover intention on BNI Life employees in West Sumatra Region. If the compensation given to BNI Life employees in West Sumatera is unfair and not in accordance with the tasks performed, the turnover of intention to employees is increasing but conversely if compensation is given fairly and accordingly, the turnover 
intention will decrease. This result is consistent with the research conducted by Widayati et al [14] compensation has a negative and significant effect on turnover intention at PT Hadico.

\section{Effect of Organizational Commitment to Turnover Intention}

Based on the results of the research hypothesis testing using the SmartPLS 3 program it is known that the influence of organizational commitment on turnover intention results in a path coefficient of -0.1430 and t-count of 0.445 . It can be concluded that the influence of organizational commitment has no significant effect on the turnover intention of BNI Life employees in the West Sumatera Region have a low commitment, it will increase turnover intention, but on the contrary if the employees commitment to the organization is high, it will reduce the turnover intention for BNI Life employees in West Sumatera Region. This result is consistent with the research conducted by Andini [1] which states that commitment negatively influences turnover intention at Roemani Hospital Muhammadiyah, Semarang

\section{Effect of Job Satisfaction to Turnover Intention}

Base on the result of the research hypothesis testing using the SmartPLS 3 program it is known that the effect of job satisfaction on turnover intention produces a path coefficient of -0.070 and $t$-count of 0.410. It can be concluded that the effect of job satisfaction has a negative and insignificant effect on the turnover of BNI Life employees in the West Sumatera Region. If the satisfaction felt by employees increase, employees will continue to survive and reduce turnover intention, but conversely if employee's satisfaction decreases, it will increase the turnover rate intention in BNI Life in West Sumatera Region. This result is consistent with the research conducted by Suhanto [9] which states that job satisfaction has a negative effect on turnover intention on employees of Bank International Indonesia.

\section{Compensation affects turnover intention through job satisfaction as an intervening variable}

Based on the results of the research hypothesis testing using the Smart PLS 3 program, it is known that the influence of organizational commitment on turnover intention results in a path coefficient of -0.070 and a t-count of 0.410 . It can be concluded that job satisfaction has a negative and not significant effect on the turnover of BNI Life employees in the West Sumatra Region. This shows that even if it does not exceed job satisfaction, compensation will still be able to influence turnover intention. This result is in accordance with the research conducted by Parashakti [5] which states that compensation has a negative effect on turnover intention through job satisfaction and the Jakarta Language Center International.

\section{Organizational commitment affects turnover intention through job satisfaction as an intervening variable}

Based on the results of testing the research hypothesis using the SmartPLS 3 program it is known that the indirect effect of compensation on turnover intention through job satisfaction results in a path coefficient of -0.059 and $\mathrm{t}$-count of 0.131 . It can be concluded that compensation has a negative and insignificant effect on the turnover of BNI Life employees in the West Sumatra Region. This shows that even without passing job satisfaction, organizational commitment will still be able to influence turnover intention. This result is in accordance with Mufidah [4] study which states that organizational commitment has a negative effect on turnover intention through job satisfaction on employees of PT. EF Sinergy Consultant.

\section{Conclusions}

1. Based on the results of the above research of the above research, It shows that compensation has a negative and significant effect on turnover intention on BNI Life employees in West Sumatra Region 
2. Based on the results of the above research of the above research, it shows that organizational commitment has no signifikant effect on the turnover of BNI Life employees in the West Sumatra Region

3. Based on the results of the above research of the above research, it shows that job satisfaction has a negative and insignificant effect on the turnover of BNI Life employees in the West Sumatra Region.

4. Based on the results of the above research the that indirect effect of compensation on job satisfaction has a negative and significant effect on the turnover of BNI Life employees in the West Sumatra Region

5. Based on the results of the above research, it shows that the indirect effect of organizational commitment to turnover intention through negative job satisfaction and not significant to the turnover of BNI Life employees in the West Sumatra Region.

\section{References}

Andini, R, 2006. Kepuasan Gaji, Kepuasan Kerja, Komitmen Organisasional Terhadap Turnover Intention.Tesis Program Pasca Sarjana MagisterManajemen Universitas Diponegoro.

Hasibuan, Melayu. (2012) Manajemen Sumber Daya Manusia, edisirevisi. Jakarta: Bumi Aksara.

N. Ulfatin and T. Triwijanto, Manajemen Sumber Daya Manusia Bidang Pendidikan [Human ResourceManagement on Education], Jakarta, Indonesia: Rajagrafindo, 2016.

Mahdi, A, F Zaid, M. Z, et al. 2012. The Relationship Between Job Satisfaction and Turnover Intention, American Journal of Applied Sciences, 9(9).

Mufidah, L, 2016. Pengaruh Job Satisfaction Terhadap Turnover Intention dengan Continuace Commitment Sebagai Variabel Intervening Pada Karyawan EF Sinergy Consultant.

Mobley, W,H. 1997. Intermediate Linkages in The Relantionship Between Job Satisfaction and Employee Turnover. Journal of Applied Psychology, (62)(2), 237-240.

Parashakti R,D., Nashar, M \& Desi U. (2017). The Effect Compensation and Organization Commitment owards Turnover Intention. Case Study ILC (International Language Center) Jakarta. Internasional Coference of Organizational Innovation (ICOI) 2012

R.L. Mathis and J.H. Jackson, Manajemen Sumber Daya Manusia [Human Resource Management], revision ed., Jakarta, Indonesia: Bumi Aksara, 2012.

Sugiyono, Metode Penelitian Pendidikan (Pendekatan Kuantitatif, Kualitatif dan RED [Educational Research Methods (Quantitative, Qualitative and R \& D Approach)], Bandung, Indonesia: CV. Alfabeta, 2015.

Suparyadi, Manajemen Sumber Daya Manusia:Menciptakan Keunggulan Bersaing Berbasis Kompetensi SDM [Human Resource Management:Creating Competitive Advantage of HR Competency Based], 1st ed., Yogyakarta, Indonesia: Andi, 2015.

Suhanto, E, 2009. Pengaruh Stres Kerja dan Iklim Organisasi Terhadap Turnover Intention dengan Kepuasan Kerja Sebagai Variabel Intervening.Tesis Program Pasca Sarjana Magister Manajemen Universitas Diponegoro.

Wibowo, Manajemen Kinerja [Performance Management], 5th ed., Jakarta, Indonesia: Rajawali Pers, 2016.

Wirawan, Manajemen Sumber Daya Manusia Indonesia - Teori, Psikologi, Hukum, Ketenagakerjaan, Aplikasi dan Penulisan: Aplikasi dalam Organisasi Bisnis, Pemerintahan dan Pendidikan [Human Resource Management of Indonesia: Theory, Psychology, Law, Employment, Application and Writing: Application in Business Organization, Government and Education]. Jakarta, Indonesia: PT Rajagrafindo Persada, 2015.

Widayati dan Yunia, 2016. Pengaruh Kompensasi dan Budaya Organisasi Terhadap Turnover Intention Pada PT Hadico. 